\title{
Indonesian Journal of Human Nutrition
}

P-ISSN 2442-6636

E-ISSN 2355-3987

www.ijhn.ub.ac.id

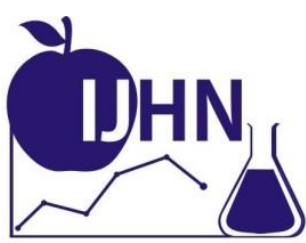

Artikel Hasil Penelitian

\section{Perbedaan Lemak Jenuh dan Tak Jenuh Keripik Labu Kuning Metode Vacuum Frying dengan Menggunakan Minyak Berulang Saturated and Unsaturated Fat Difference of Pumpkin Chips Processed using Vacuum Frying}

\author{
Titis Sari Kusuma ${ }^{1 *}$, Adelya Desi Kurniawati ${ }^{1}$, Rizal Fakih Firmansyah ${ }^{1}$, Elly \\ Septiana ${ }^{1}$ \\ ${ }^{1 *}$ Program Studi Ilmu Gizi, Fakultas Kedokteran Universitas Brawijaya, \\ Email : titis_fahreza.fk@ub.ac.id, Tlp : 08123357197 \\ * Alamat korespondensi: titis_fahreza.fk@ub.ac.id.
}

\begin{abstract}
People nowadays tend to consume fast foods containing high calory, low fiber, high saturated fat, and cholesterol, which lead to metabolic syndromes, such as dyslipidemia. Pumpkin contains less cholesterol and has been processed into chips through the Vacuum Frying method, allowing a preserved quality outcome and reducing the damage of cooking oil due to hydrolysis. This research aimed to investigate the difference of saturated and unsaturated fat content in pumpkin chips, produced through the Vacuum Frying method and reused oil in the $1^{\text {st }}, 5^{\text {th }}$, and $10^{\text {th }}$ frying process. This research was carried out based on the Quasi-Experimental methodology with three groups and two replications. The analysis of saturated fatty acids was undertaken by performing GC-FID, while unsaturated fatty acids were analyzed using gas chromatography. Data were processed using SPSS Version 21.0 implementing the Shapiro Wilk test followed by the Kruskal Wallis test. The findings show no difference in saturated fatty acid levels $(p>0.05)$ and no decrease in the levels of palmitoleic acid ( $p=0.565)$, alpha-linolenic acid $(p=0.156)$, and gamma-linolenic acid $(p=0.276)$ in pumpkin chips. The absence of changes in saturated and unsaturated fatty acid levels allows pumpkin chips to become an alternative snack for people with dyslipidemia.
\end{abstract}

Keywords: pumpkin chips, saturated fatty acids, unsaturated fatty acids, Vacuum Frying.

\begin{abstract}
ABSTRAK
Masyarakat saat ini cenderung untuk mengonsumsi fast food yang mengandung tinggi kalori, rendah serat, tinggi lemak jenuh dan kolesterol yang dapat memicu terjadinya sindrom metabolik salah satunya dislipidemia. Labu kuning memiliki kadar kolesterol rendah dan pengolahan menjadi keripik dengan metode Vacuum Frying bertujuan untuk mempertahankan kualitas bahan pangan dan mengurangi kerusakan pada minyak goreng akibat hidrolisis. Tujuan dari penelitian ini adalah untuk mengetahui perbedaan kadar asam lemak jenuh dan tak jenuh keripik labu kuning metode Vacuum Frying dengan penggunaan minyak berulang pada kelipatan penggorengan ke 1, ke 5 dan ke 10. Metode penelitian ini bersifat Quasi Eksperimental dengan 3 kelompok dan 2 kali replikasi.
\end{abstract}


Pengujian kadar asam lemak jenuh menggunakan metode GC FID dan asam lemak tak jenuh dengan metode kromatografi gas. Data dianalisa menggunakan SPSS Versi 21.0 dengan uji shapiro wilk dilanjutkan uji kruskal wallis. Hasil penelitian ini adalah tidak ada perbedaan kadar asam lemak jenuh $(\mathrm{p}>0,05)$, tidak ada penurunan kadar asam palmitoleat $(\mathrm{p}=0,565)$, asam alpha linolenat $(\mathrm{p}=0,156)$ dan asam gamma linolenat $(\mathrm{p}=0,276)$ pada keripik labu kuning. Karena tidak ada perubahan kadar asam lemak jenuh dan tak jenuh, maka keripik labu kuning dapat dijadikan alternatif snack bagi penderita dislipidemia.

Kata kunci: Asam lemak jenuh, asam lemak tak jenuh, keripik labu kuning, Vacuum Frying.

\section{PENDAHULUAN}

Masyarakat sekarang ini cenderung untuk mengonsumsi cemilan berlebih, instan dan fast food. Faktanya makanan tersebut memiliki kandungan kalori yang tingi, rendah serat dan tinggi lemak terutama kandungan lemak jenuh dan kolesterol. Hal ini dapat menimbulkan ketidakseimbangan asupan gizi yang berdampak pada masalah kesehatan seperti sindrom metabolik. Prevalensi kejadian sindroma metabolik yang masih tinggi angkanya yaitu dislipidemia (35,9\% gangguan kolesterol total, 15,9\% LDL tinggi, 11,9\% trigliserida tinggi dan 22,9\% $\mathrm{HDL}$ rendah)[1]. Ada beberapa cara yang diperlukan untuk menurunkan risiko sindrom metabolik seperti mengonsumsi asam lemak tak jenuh tunggal yang dapat menurunkan hipertrigliseridemia yang dapat memperbaiki keadaan sindrom metabolik, mengonsumsi asam lemak tak jenuh ganda yang dapat meningkatkan HDL dan meningkatkan elastisitas pembuluh darah serta meningkatkan ketersediaan makanan rendah kolesterol [2].

Labu kuning (cucurbita moschata) termasuk komoditas tanaman lokal yang banyak dijumpai di Indonesia, kandungan betakarotennya yang tinggi sebesar 1569 $\mathrm{mcg} / 100 \mathrm{~g}$ memberikan manfaat sebagai sumber antioksidan untuk mencegah dan menangani stress oksidatif yang timbul karena produksi ROS yang berlebih serta kandungan kolesterolnya yang rendah $[3,4]$. Labu kuning berperan penting untuk mencegah penyakit tidak menular seperti aterosklerosis, jantung koroner, diabetes mellitus, mencegah kanker dan tekanan darah tinggi [5].

Labu kuning dapat dinikmati secara langsung setelah dikukus atau diolah menjadi panganan lainnya seperti kolak, kroket dan donat. Namun olahan labu kuning tersebut umumnya memiliki kandungan lemak dan gula yang tinggi. Selain itu karena sifatnya yang basah, olahan seperti itu memiliki masa simpan yang relatif singkat. Sehingga dipilih olahan keripik karena bersifat kering, memiliki kandungan gizi yang stabil tanpa mengubah rasa dan aroma.

Olahan keripik memerlukan minyak goreng sebagai media panas, dimana salah satu komponen penyusunnya yaitu asam lemak jenuh. Asam lemak jenuh akan mudah mengalami kerusakan ketika dilakukan metode penggorengan secara konvensional dan deep fat frying, yaitu pada suhu penggorengan $160^{\circ} \mathrm{C}-180^{\circ} \mathrm{C}$ [6,7]. Vacuum Frying merupakan metode menggoreng pada bahan pangan peka panas seperti, sayuran dan buah-buahan yang bertujuan untuk menghasilkan olahan keripik namun karakteristik bahan pangan seperti, aroma, rasa dan nilai gizinya relatif dapat dipertahankan $[8,9]$.

Berdasarkan hal tersebut, peneliti ingin mengetahui lebih lanjut mengenai perbedaan kadar asam lemak jenuh dan tak jenuh pada keripik labu kuning menggunakan metode penggorengan Vacuum Frying dengan penggunaan minyak berulang sebagai alternatif snack 
sehat bagi penderita sindrom metabolik terutama dislipidemia.

\section{METODE PENELITIAN}

\section{Rancangan Penelitian}

Quasi Eksperimental. Penelitian sebelumnya mengenai kadar asam lemak jenuh pada penggorengan keripik pisang kepok metode vaccum frying yang dilakukan penggorengan sebanyak 5 (lima) kali telah menunjukkan kadar asam lemak jenuh [18]. Hal tersebut menjadikan dasar bagi peneliti untuk membuat rancangan penelitian penggorengan keripik labu kuning metode Vacuum Frying dengan penggunaan minyak berulang pada kelipatan penggorengan ke 5 (lima). Minyak goreng yang digunakan adalah Minyak Sawit Merk Rose Brand. Sampel penelitian ini pada tingkat penggorengan ke 1 , ke 5 dan ke 10 sehingga total sampel penelitian sebanyak 6 (enam) sampel. Keterangan perlakuan dan replikasi terdapat pada tabel 1 .

Tabel 1. Rancangan Penelitian

\begin{tabular}{ccc}
\hline \multirow{2}{*}{ Perlakuan } & \multicolumn{2}{c}{ Replikasi } \\
\cline { 2 - 3 } & Replikasi 1 & Replikasi 2 \\
\hline P1 & P1R1 & P1R1 \\
P5 & P5R1 & P5R2 \\
P10 & P10R1 & P10R2 \\
\hline
\end{tabular}

\section{Sumber Data}

Data didapatkan dari hasil pengujian kadar asam lemak jenuh dan asam lemak tak jenuh. Penelitian diawali dengan pembuatan keripik labu kuning dilakukan di Laboratorium Penyelenggaraan Makan Jurusan Gizi Fakultas Kedokteran Universitas Brawijaya Malang. Dilanjutkan dengan uji kadar asam lemak jenuh dan kadar asam lemak tak jenuh pada keripik labu kuning di Laboratorium SIG PT. Saraswanti Indo Genetech Bogor.

\section{Sasaran Penelitian}

Populasi penelitian ini adalah semua labu kuning yang dibeli di Pasar Gadang, Kota Malang. Sampel dalam penelitian ini adalah labu kuning jenis bokor yang sudah disortasi sesuai dengan kriteria inklusi dan eksklusi. Kriteria inklusi yaitu umur buah labu kuning 3 sampai 5 bulan (kategori masak), daging buah labu kuning berwarna oranye, kulit tidak cacat (tidak ada luka fisik bekas potongan/sayatan selama masa panen) dan daging buah labu kuning tidak terlalu lembek. Kriteria eksklusi yang digunakan adalah umur buah labu kuning kurang dari 3 bulan (kategori mentah), daging buah tidak berwarna oranye, kulit cacat, daging buah labu kuning terlalu lembek atau keras.

\section{Pengembangan Instrumen dan Teknik Pengumpulan Data}

Alat yang digunakan dalam pemuatan keripik labu kuning adalah adalah timbangan bahan makanan, baskom, talenan, pisau, sendok, serokan, mesin vacuum frying dengan kapasitas 1 $\mathrm{kg}$, lemari pendingin (freezer), spiner, slicer, vortex, labu erlenmeyer, tabung reaksi. Alat yang digunakan untuk pengujian asam lemak jenuh meliputi : timbangan analitik, pisau, labu soxhlet, oven, termometer, penangas air, gelas ukur, vortex, pipet tetes dan peralatan kromatografi gas GC-MS. Adapun untuk pengujian asam lemak tak jenuh adalah timbangan analitik, pisau, labu ukur, oven, thermometer, penangas air, gelas ukur, vortex, pipet tetes dan peralatan kromatografi gas.

Bahan yang digunakan dalam penelitian pembuatan keripik labu kuning adalah buah labu kuning yang telah disortasi dan dipilih daging buah yang sesuai spesifikasi minyak goreng merk rosebrand, Natrium Metabisulfit $\left(\mathrm{Na}_{2} \mathrm{~S}_{2} \mathrm{O}_{5}\right) 1000$ ppm dan. $\mathrm{NaHSO}_{3}$ 0,1\%.

\section{Teknik Analisis Data}


Data penelitian ini dianalisis menggunakan SPSS 21.0. Data dilakukan uji normalitas data menggunakan uji Shapiro Wilk menunjukkan sebagian data tidak terdistribusi normal ( $\mathrm{p}$-value < 0,05) dan uji homogenitas data menggunakan Homogenitas Welch menunjukkan data tidak homogen ( $p$ value $>0,05)$ sehingga uji statistik dilanjutkan dengan uji non parametrik Kruskal Wallis. Langkah-langkah penelitian utama terdapat pada gambar 1 .

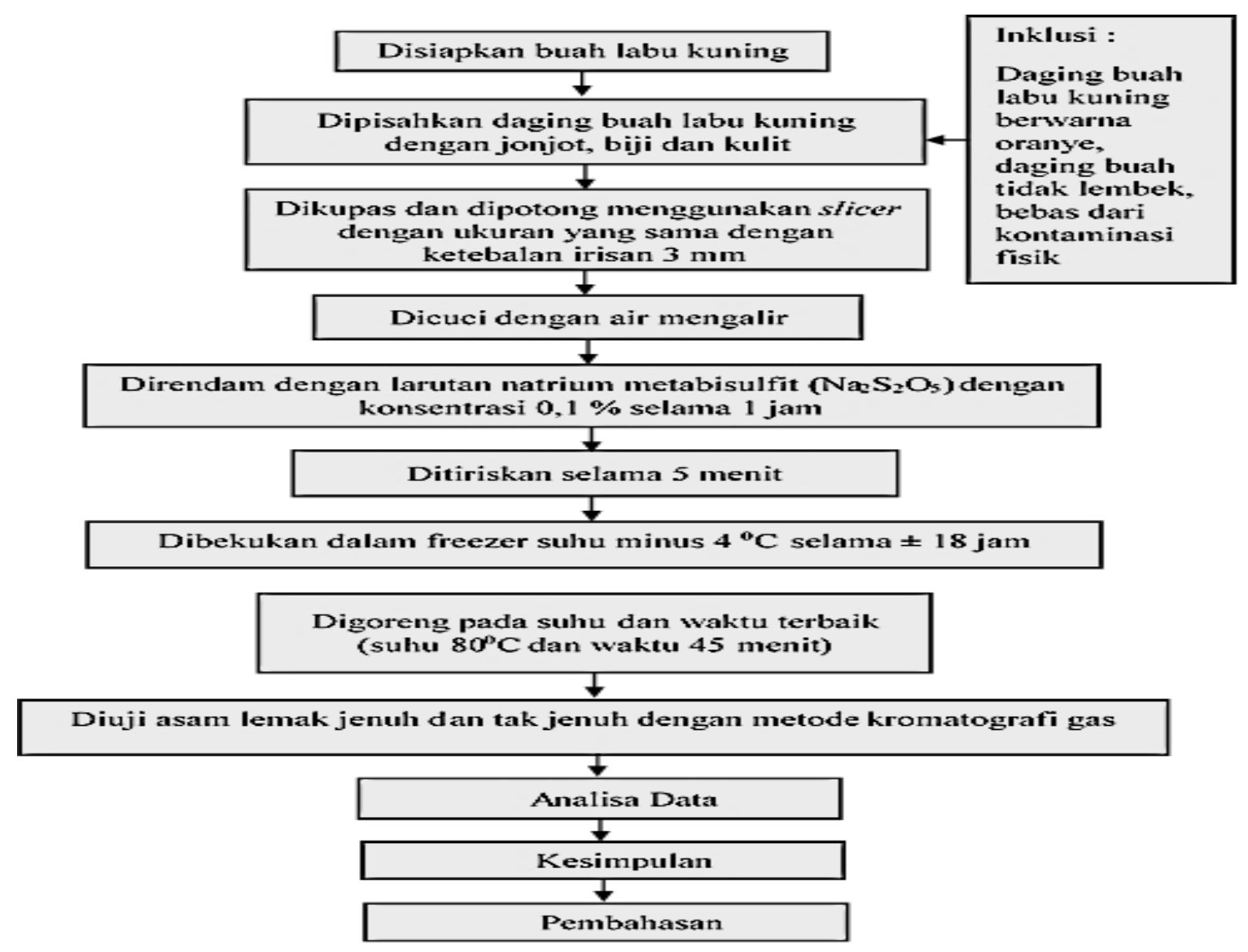

Gambar 1. Diagram Alir Penelitian Utama

\section{HASIL PENELITIAN}

\section{Kadar Asam Lemak Jenuh Rantai}

Sedang (C8-C13)

Hasil uji kadar asam lemak jenuh rantai sedang menggunakan metode GDFID dan analisa data menggunakan uji normalitas data Shapiro Wilk menunjukkan data terdistribusi normal dan uji beda menggunakan Kruskal Wallis meliputi: asam kaprat, asam kaprilat dan asam laurat dapat dilihat pada tabel 2.

\section{Kadar Asam Lemak Jenuh Rantai Panjang (C14-C20)}

Hasil uji kadar asam lemak jenuh rantai panjang menggunakan metode GDFID dan analisa data menggunakan uji normalitas data Shapiro Wilk menunjukkan sebagian data terdistribusi normal dan uji beda menggunakan Kruskal Wallis meliputi: asam mirisat, asam pentadekanoat, asam palmiat, asam heptadekanoat, asam stearat dan asam arachidat dapat dilihat pada tabel 3.

Kadar Asam Lemak Jenuh Rantai Sangat Panjang ( > C20) 
Hasil uji kadar asam lemak jenuh rantai sangat panjang meliputi: asam behenat, asam trikosanoat dan asam lignoserat menggunakan metode GC-FID dan analisa data menggunakan uji normalitas data Shapiro Wilk

Hasil uji kadar asam lemak tak jenuh tunggal metode Kromatografi Gas dan analisis data dengan menggunakan uji beda Kruskal Wallis. Berdasarkan Analisa perbedaan asam lemak tak jenuh tunggal keripik labu kuning metode Vacuum Frying dengan penggunaan minyak berulang hanya ditemukan kadar asam palmitoleat yang terdistribusi normal. Hasil analisa secara uji statistik perbedaan adar asam pamitoleat pada keripik labu kuning metode Vacuum Frying dengan minyak berulang tidakk ada perbedaan signifikan $(\mathrm{p}>0,05)$ pada kadar asam palmitoleat pada setiap penggorengan seperti pada Tabel 5 .

\section{Kadar Asam Lemak Tak Jenuh Ganda (PUFA) Asam Lemak Omega 3}

Hasil uji kadar asam lemak tak jenuh ganda Omega-3 metode Kromatografi Gas dan analisa data dengan menggunakan uji beda Kruskal Wallis. Berdasarkan analisa perbedaan asam lemak tak jenuh ganda Omega-3 keripik labu kuning metode Vacuum Frying dengan penggunaan minyak berulang hanya ditemukan kadar asam menunjukkan sebagian data terdistribusi normal dan uji beda menggunakan Kruskal Wallis dapat dilihat pada tabel 4.

\section{Kadar Asam Lemak Tak Jenuh Tunggal (MUFA)}

alfa linolenat yang terdistribusi normal. Hasil analisa secara uji statistik perbedaan kadar asam alfa linolenat pada keripik labu kuning metode Vacuum Frying dengan minyak berulang tidak ada perbedaan signifikan $(\mathrm{p}>0,05)$ pada kadar asam alfa linolenat pada setiap penggorengan seperti pada tabel 6 .

\section{Kadar Asam Lemak Tak Jenuh Ganda (PUFA) Omega 6}

Hasil uji kadar asam lemak tak jenuh ganda Omega-6 metode Kromatografi Gas dan analisis data dengan menggunakan uji beda Kruskal Wallis.Berdasarkan analisa perbedaan asam lemak tak jenuh ganda Omega-6 keripik labu kuning metode Vacuum Frying dengan penggunaan minyak berulang hanya ditemukan kadar asam gamma linolenat yang terdistribusi normal. Hasil analisa secara uji statistik perbedaan kadar asam gamma linolenat pada keripik labu kuning metode Vacuum Frying dengan minyak berulang tidak ada perbedaan signifikan $(\mathrm{p}>0,05)$ pada kadar asam gamma linolenat pada setiap penggorengan seperti pada tabel 7 .

Tabel 2. Hasil dan Analisa Kadar Asam Lemak Jenuh Rantai Sedang Keripik Labu Kuning Dalam 100 gram Bahan

\begin{tabular}{|c|c|c|c|c|c|c|}
\hline $\begin{array}{c}\text { Jenis Asam Lemak } \\
\text { Jenuh }\end{array}$ & $\begin{array}{c}\text { Kelompok } \\
\text { Penggorengan }\end{array}$ & $\begin{array}{c}\text { Nilai } \\
\text { Median } \\
(\%)\end{array}$ & $\begin{array}{c}\text { Nilai } \\
\text { Minimum } \\
(\%)\end{array}$ & $\begin{array}{c}\text { Nilai } \\
\text { Maksimum } \\
(\%)\end{array}$ & $\begin{array}{c}\text { Uji } \\
\text { Normalitas } \\
p \text {-value }\end{array}$ & $\begin{array}{l}\text { Uji Kruskal } \\
\text { Wallis } \\
p \text {-value }\end{array}$ \\
\hline \multirow{3}{*}{$\begin{array}{c}\text { Asam Kaprilat } \\
\left(\mathrm{C}_{8}\right)\end{array}$} & $\mathrm{P} 1$ & \multirow{3}{*}{0,0065} & \multirow{3}{*}{0,0035} & \multirow{3}{*}{0,0520} & \multirow{3}{*}{0,822} & \multirow{3}{*}{0,565} \\
\hline & P5 & & & & & \\
\hline & P10 & & & & & \\
\hline \multirow{3}{*}{$\begin{array}{l}\text { Asam Kaprat } \\
\left(\mathrm{C}_{10}\right)\end{array}$} & $\mathrm{P} 1$ & \multirow{3}{*}{0,0070} & \multirow{3}{*}{0,0046} & \multirow{3}{*}{0,0088} & \multirow{3}{*}{0,917} & \multirow{3}{*}{0,156} \\
\hline & P5 & & & & & \\
\hline & P10 & & & & & \\
\hline \multirow{3}{*}{$\begin{array}{l}\text { Asam Laurat } \\
\left(\mathrm{C}_{12}\right)\end{array}$} & P1 & \multirow{3}{*}{0,0725} & \multirow{3}{*}{0,0477} & \multirow{3}{*}{0,0903} & \multirow{3}{*}{0,487} & \multirow{3}{*}{0,156} \\
\hline & P5 & & & & & \\
\hline & P10 & & & & & \\
\hline
\end{tabular}


Tabel 3. Hasil dan Analisa Kadar Asam Lemak Jenuh Rantai Panjang Keripik Labu Kuning Dalam 100 gram Bahan

\begin{tabular}{|c|c|c|c|c|c|c|}
\hline $\begin{array}{c}\text { Jenis Asam Lemak } \\
\text { Jenuh }\end{array}$ & $\begin{array}{c}\text { Kelompok } \\
\text { Penggorengan }\end{array}$ & $\begin{array}{c}\text { Nilai } \\
\text { Median } \\
(\%)\end{array}$ & $\begin{array}{c}\text { Nilai } \\
\text { Minimum } \\
(\%)\end{array}$ & $\begin{array}{c}\text { Nilai } \\
\text { Maksimum } \\
(\%)\end{array}$ & $\begin{array}{c}\text { Uji } \\
\text { Normalitas } \\
p \text {-value }\end{array}$ & $\begin{array}{c}\text { Uji Kruskal } \\
\text { Wallis } \\
p \text {-value } \\
\end{array}$ \\
\hline \multirow{3}{*}{$\begin{array}{l}\text { Asam Miristat } \\
\left(\mathrm{C}_{14}\right)\end{array}$} & $\mathrm{P} 1$ & \multirow{3}{*}{0,4381} & \multirow{3}{*}{0,2403} & \multirow{3}{*}{0,4653} & \multirow{3}{*}{0,004} & \multirow{3}{*}{0,102} \\
\hline & P5 & & & & & \\
\hline & P10 & & & & & \\
\hline \multirow{3}{*}{$\begin{array}{c}\text { Asam } \\
\text { Pentadekanoat } \\
\left(\mathrm{C}_{15}\right)\end{array}$} & $\mathrm{P} 1$ & \multirow{3}{*}{0,0145} & \multirow{3}{*}{0,0102} & \multirow{3}{*}{0,0207} & \multirow{3}{*}{0,196} & \multirow{3}{*}{0,565} \\
\hline & P5 & & & & & \\
\hline & P10 & & & & & \\
\hline \multirow{3}{*}{$\begin{array}{c}\text { Asam Palmitat } \\
\left(\mathrm{C}_{16}\right)\end{array}$} & $\mathrm{P} 1$ & \multirow{3}{*}{18,5954} & \multirow{3}{*}{10,0562} & \multirow{3}{*}{19,5717} & \multirow{3}{*}{0,001} & \multirow{3}{*}{0,276} \\
\hline & P5 & & & & & \\
\hline & P10 & & & & & \\
\hline \multirow{3}{*}{$\begin{array}{c}\text { Asam } \\
\text { Heptadekanoat } \\
\left(\mathrm{C}_{17}\right)\end{array}$} & $\mathrm{P} 1$ & \multirow{3}{*}{0,0419} & \multirow{3}{*}{00236} & \multirow{3}{*}{0,0443} & \multirow{3}{*}{0,003} & \multirow{3}{*}{0,102} \\
\hline & P5 & & & & & \\
\hline & $\mathrm{P} 10$ & & & & & \\
\hline \multirow{3}{*}{$\begin{array}{l}\text { Asam Stearat } \\
\left(\mathrm{C}_{18}\right)\end{array}$} & $\mathrm{P} 1$ & \multirow{3}{*}{2,5332} & \multirow{3}{*}{1,2487} & \multirow{3}{*}{3,0556} & \multirow{3}{*}{0,304} & \multirow{3}{*}{0,867} \\
\hline & P5 & & & & & \\
\hline & $\mathrm{P} 10$ & & & & & \\
\hline \multirow{3}{*}{$\begin{array}{c}\text { Asam Arachidat } \\
\left(\mathrm{C}_{20}\right)\end{array}$} & $\mathrm{P} 1$ & \multirow{3}{*}{0,1861} & \multirow{3}{*}{0,1044} & \multirow{3}{*}{0,2002} & \multirow{3}{*}{0,002} & \multirow{3}{*}{0,368} \\
\hline & P5 & & & & & \\
\hline & P10 & & & & & \\
\hline
\end{tabular}

Keterangan : P1 = Penggorengan 1, P5 = Penggorengan 5, P10 = Penggorengan

Tabel 4. Hasil dan Analisa Kadar Asam Lemak Jenuh Rantai Sangat Panjang Keripik Labu Kuning Dalam 100 gram Bahan

\begin{tabular}{|c|c|c|c|c|c|c|}
\hline $\begin{array}{c}\text { Jenis Asam Lemak } \\
\text { Jenuh }\end{array}$ & $\begin{array}{c}\text { Kelompok } \\
\text { Penggorengan }\end{array}$ & $\begin{array}{c}\text { Nilai } \\
\text { Median } \\
(\%)\end{array}$ & $\begin{array}{c}\text { Nilai } \\
\text { Minimum } \\
(\%)\end{array}$ & $\begin{array}{c}\text { Nilai } \\
\text { Maksimum } \\
\quad(\%)\end{array}$ & $\begin{array}{c}\text { Uji } \\
\text { Normalitas } \\
p \text {-value }\end{array}$ & $\begin{array}{c}\text { Uji } \\
\text { Kruskal } \\
\text { Wallis } \\
\text { p-value } \\
\end{array}$ \\
\hline \multirow{3}{*}{$\begin{array}{c}\text { Asam Behenat } \\
\left(\mathrm{C}_{22}\right)\end{array}$} & $\mathrm{P} 1$ & \multirow{3}{*}{0,0341} & \multirow{3}{*}{0,0193} & \multirow{3}{*}{0,0363} & \multirow{3}{*}{0,001} & \multirow{3}{*}{0,497} \\
\hline & P5 & & & & & \\
\hline & $\mathrm{P} 10$ & & & & & \\
\hline \multirow{3}{*}{$\begin{array}{c}\text { Asam Trikosanoat } \\
\left(\mathrm{C}_{23}\right)\end{array}$} & P1 & \multirow{3}{*}{0,0080} & \multirow{3}{*}{0,0046} & \multirow{3}{*}{0,0086} & \multirow{3}{*}{0,007} & \multirow{3}{*}{0,773} \\
\hline & P5 & & & & & \\
\hline & $\mathrm{P} 10$ & & & & & \\
\hline \multirow{3}{*}{$\begin{array}{c}\text { Asam Lignoserat } \\
\left(\mathrm{C}_{24}\right)\end{array}$} & P1 & \multirow{3}{*}{0,0411} & \multirow{3}{*}{0,0230} & \multirow{3}{*}{0,0421} & \multirow{3}{*}{0,000} & \multirow{3}{*}{0,565} \\
\hline & P5 & & & & & \\
\hline & P10 & & & & & \\
\hline
\end{tabular}

Keterangan $: \mathrm{P} 1$ = Penggorengan 1, P5 = Penggorengan 5, P10 = Penggorengan 
Tabel 5. Hasil Analisis Kadar Asam Lemak Tak Jenuh Tunggal Keripik Labu Kuning dalam 100 gram Bahan

\begin{tabular}{|c|c|c|c|c|c|c|}
\hline $\begin{array}{c}\text { Jenis Asam } \\
\text { Lemak Tak } \\
\text { Jenuh }\end{array}$ & $\begin{array}{c}\text { Kelompok } \\
\text { Penggorengan }\end{array}$ & $\begin{array}{c}\text { Nilai } \\
\text { Median } \\
(\%)\end{array}$ & $\begin{array}{c}\text { Nilai } \\
\text { Minimal } \\
(\%)\end{array}$ & $\begin{array}{c}\text { Nilai } \\
\text { Maximal } \\
(\%)\end{array}$ & $\begin{array}{c}\text { Uji } \\
\text { Normalitas } \\
p \text {-value }\end{array}$ & $\begin{array}{c}\text { Uji Kruskal } \\
\text { Wallis } \\
p \text {-value }\end{array}$ \\
\hline $\begin{array}{l}\text { Palmitoleat } \\
\qquad\left(\mathrm{C}_{16: 1}\right)\end{array}$ & $\begin{array}{c}\text { P1 } \\
\text { P5 } \\
\text { P10 }\end{array}$ & 0,0532 & 0,0351 & 0,0868 & 0,636 & 0,565 \\
\hline
\end{tabular}

Tabel 6 Hasil Analisis Kadar Asam Lemak Tak Jenuh Ganda Keripik Labu Kuning dalam 100 gram Bahan

\begin{tabular}{|c|c|c|c|c|c|c|}
\hline $\begin{array}{c}\text { Jenis Asam } \\
\text { Lemak Tak Jenuh }\end{array}$ & $\begin{array}{c}\text { Kelompok } \\
\text { Penggorengan }\end{array}$ & $\begin{array}{l}\text { Nilai } \\
\text { Median } \\
(\%)\end{array}$ & $\begin{array}{c}\text { Nilai } \\
\text { Minimal } \\
(\%)\end{array}$ & $\begin{array}{c}\text { Nilai } \\
\text { Maximal } \\
(\%)\end{array}$ & $\begin{array}{c}\text { Uji } \\
\text { Normalitas } \\
p \text {-value }\end{array}$ & $\begin{array}{c}\text { Uji Kruskal } \\
\text { Wallis } \\
p \text {-value }\end{array}$ \\
\hline \multirow{3}{*}{$\begin{array}{l}\text { Asam } \alpha \text { Linolenat } \\
\quad(\mathrm{C} 18: 3 \omega 3)\end{array}$} & $\mathrm{P} 1$ & \multirow{3}{*}{0,1387} & \multirow{3}{*}{0,1081} & \multirow{3}{*}{0,1914} & \multirow{3}{*}{0,924} & \multirow{3}{*}{0,156} \\
\hline & P5 & & & & & \\
\hline & P10 & & & & & \\
\hline
\end{tabular}

Keterangan : P1 = Penggorengan 1, P5 = Penggorengan 5, P10 = Penggorengan 10

Tabel 7 Hasil Analisis Kadar Asam Lemak Tak Jenuh Ganda Keripik Labu Kuning dalam 100 gram Bahan

\begin{tabular}{|c|c|c|c|c|c|c|}
\hline $\begin{array}{c}\text { Jenis Asam Lemak Tak } \\
\text { Jenuh }\end{array}$ & $\begin{array}{c}\text { Kelompok } \\
\text { Penggorengan }\end{array}$ & $\begin{array}{c}\text { Nilai } \\
\text { Media } \\
\text { n } \\
(\%)\end{array}$ & $\begin{array}{c}\text { Nilai } \\
\text { Minimal } \\
(\%)\end{array}$ & $\begin{array}{c}\text { Nilai } \\
\text { Maximal } \\
(\%)\end{array}$ & $\begin{array}{c}\text { Uji } \\
\text { Normalita } \\
\text { S } \\
p \text {-value }\end{array}$ & $\begin{array}{c}\text { Uji Kruskal } \\
\text { Wallis } \\
p \text {-value }\end{array}$ \\
\hline \multirow{3}{*}{ 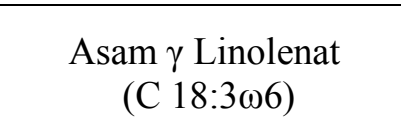 } & $\mathrm{P} 1$ & \multirow{3}{*}{0,0181} & \multirow{3}{*}{0,0071} & \multirow{3}{*}{0,0193} & \multirow{3}{*}{0,004} & \multirow{3}{*}{0,276} \\
\hline & P5 & & & & & \\
\hline & $\mathrm{P} 10$ & & & & & \\
\hline
\end{tabular}

Keterangan : P1 = Penggorengan 1, P5 = Penggorengan 5, P10 = Penggorengan 10

\section{PEMBAHASAN}

Kadar Asam Lemak Jenuh Rantai Sedang (C8-C13)

Berdasarkan tabel 2 diatas menunjukkan tidak adanya perbedaan ketiga asam lemak jenuh rantai sedang yaitu asam kaprilat, asam kaprat dan asam laurat pada keripik labu kuning dengan penggorengan metode Vacuum Frying, baik pada penggorengan ke 1, ke 5 dan ke 10 ( $\mathrm{p}>0,05)$. Hal ini sependapat dengan Herlina dkk., 2017 bahwa suhu penggorengan pada kondisi vakum dapat dikendalikan antara suhu $80{ }^{\circ} \mathrm{C}$ hingga 90 ${ }^{\circ} \mathrm{C}$ sehingga titik didih minyak dapat diturunkan. Penurunan titik didih minyak menyebabkan kerusakan warna, aroma, rasa dan nutrisi pada bahan pangan akibat panas dapat dihindari [10].

Berbeda dengan penggorengan menggunakan metode deep fat frying, dimana suhu penggorengan berkisar 
$175^{\circ} \mathrm{C}-195^{\circ} \mathrm{C}$ selama 5-10 menit mengakibatkan penurunan asam lemak jenuh rantai sedang yaitu asam kaprilat menurun dari $0,02 \%$ menjadi $0,00 \%$ dan asam laurat menurun dari $0,17 \%$ menjadi $0,14 \%$ setelah dilakukan penggorengan [11]. Ketika dilakukan pemanasan atau penggorengan deep fat frying, asam lemak jenuh rantai pendek dan sedang (total Catom < 14) akan bersifat volatil atau mudah menguap. Hal ini disebabkan asam lemak jenuh rantai pendek atau sedang tersebut mengalami hidrolisis sehingga uap air dari hasil produk penggorengan akan mengakibatkan gliserida melepaskan asam lemak bebas. Selain itu, sifat volatil dari minyak/lemak pada saat proses penggorengan akan mengakibatkan peningkatan pembentukan asap (smoke development) [12].

Rata-rata total asam lemak jenuh rantai sedang pada keripik labu kuning dengan metode Vacuum Frying pada penggorengan ke 1 , ke 5 dan ke 10 didapat sebesar 0,094\% sedangkan kadar asam lemak jenuh pada daging labu kuning segar sebesar $0,001 \%$ dan pada minyak goreng kelapa sawit sebesar $0,2 \%$ $[13,14]$. Hal tersebut menunjukkan kadar asam lemak jenuh rantai sedang pada keripik labu kuning sebagian besar diperoleh pada minyak goreng kelapa sawit.

\section{Kadar Asam Lemak Jenuh Rantai Panjang (C14-C20)}

Berdasarkan Tabel 3 diatas menunjukkan tidak adanya perbedaan asam lemak jenuh rantai sedang yaitu asam miristat, asam pentadekanoat, asam palmitat, asam heptadekanoat, asam stearat dan aam arachidat pada keripik labu kuning metode Vacuum Frying, baik pada penggorengan ke 1 , ke 5 dan ke 10 $(p>0,05)$. Tidak adanya perbedaan kadar asam lemak jenuh rantai panjang menunjukkan penurunan titik didih minyak goreng pada kondisi vakum lebih rendah daripada titik didih asam lemak jenuh rantai panjang. Berikut masingmasing titik didih asam lemak jenuh rantai panjang: asam miristat $\left(250,5^{\circ} \mathrm{C}\right)$, asam pentadekanoat $\left(339,1^{\circ} \mathrm{C}\right)$, asam palmitat $\left(215^{\circ} \mathrm{C}\right)$ dan asam stearat $\left(383^{\circ} \mathrm{C}\right)$ [15]. Menurut Anwariyah dkk.(2018), penggorengan metode Vacuum Frying menurunkan titik didih minyak antara suhu penggorengan $70^{\circ} \mathrm{C}$ $85^{\circ} \mathrm{C}$ sehingga dapat menurunkan laju kerusakan minyak goreng dan menghasilkan produk olahan bahan pangan yang berkualitas.

Lain halnya, ketika minyak dilakukan proses pemanasan atau penggorengan pada temperatur yang tinggi $\left(160^{\circ} \mathrm{C}-200^{\circ} \mathrm{C}\right)$ menyebabkan minyak mudah mengalami hidrolisis $[10,16]$. Hidrolisis merupakan reaksi pelepasan asam lemak bebas akibat adanya air pada bahan pangan yang digoreng dan penggunaan suhu tinggi pada saat penggorengan. Pembentukan asam lemak bebas menyebabkan minyak/lemak mudah mengalami penurunan titik asap. Selain itu, pembentukan asam lemak bebas menyebabkan minyak/lemak lebih mudah mengalami oksidasi atau dengan kata lain minyak/lemak mudah mengalami ketengikan (ketengikan hidrolitik) [17].

Hasil penelitian keripik labu kuning dengan metode Vacuum Frying pada penggorengan ke 1 , ke 5 dan ke 10 diperoleh rata-rata total asam lemak jenuh rantai panjang sebesar 20,3874\% sedangkan kadar asam lemak jenuh pada daging labu kuning segar sebesar 0,046\% dan pada minyak goreng kelapa sawit sebesar 50,0\% [13,14]. Kadar asam lemak jenuh rantai panjang pada keripik labu kuning sebagian besar diperoleh pada minyak goreng kelapa sawit.

\section{Kadar Asam Lemak Jenuh Rantai Sangat Panjang ( > C20)}

Berdasarkan tabel 4 diatas menunjukkan tidak adanya perbedaan 
asam lemak jenuh rantai sedang yaitu asam behenat, asam trikosanoat dan asam lignoserat pada keripik labu kuning metode Vacuum Frying, baik pada penggorengan ke 1 , ke 5 dan ke 10 (p > $0,05)$. Hal ini sejalan dengan pendapat Lastriyanto dkk., 2016, bahwa penggorengan menggunakan Vacuum Frying memungkinkan untuk menggoreng bahan pangan peka panas, seperti sayuran dan buah-buahan. Selain itu, penggorengan pada suhu rendah meminimalkan kerusakan minyak goreng akibat proses pemanasan [8].

Panjang pendeknya rantai asam lemak mempengaruhi tinggi rendahnya titik asap (smoke point) dan titik nyala (fire point), oleh karenanya asam lemak jenuh rantai sangat panjang memiliki titik asap dan titik nyala lebih tinggi apabila dibandingkan dengan asam lemak dengan rantai pendek [13]. Titik asap dan titik nyala merupakan kriteria mutu minyak yang digunakan sebagai media untuk menggoreng [18]. Penurunan titik asap menunjukkan minyak akan mengeluarkan asap ketika dilakukan pemanasan pada suhu yang lebih rendah [17].

\section{Perbedaan Prosesmetabolisme Asam Lemak Jenuh Rantai Pendek, Rantai Sedang, Rantai Panjang dan Rantai Sangat Panjang}

Asam lemak jenuh dengan rantai pendek (C3-C7) dan rantai sedang (C8C13) dilakukan langsung oleh vena porta dan dibawa ke hati untuk segera dioksidasi [19]. Namun, asam lemak jenuh rantai sedang lebih direkomendasikan untuk kesehatan dikarenakan tidak mudah mengalami hidrolisis dibandingkan asam lemak jenuh rantai pendek dan lebih cepat diserap oleh tubuh $[19,20]$.

Berbeda untuk asam lemak jenuh berantai panjang (> C14) tidak dapat langsung segera diserap oleh dinding usus, namun terlebih dahulu dihidrolisa menjadi asam-asam lemak berukuran kecil. Selanjutnya, dilakukan proses emulsi dengan bantuan cairan empedu dan proses enzimatik oleh enzim yang berasal dari kelenjar penkreas, kemudian dapat diserap oleh dinding usus halus diubah kembali menjadi bentuk trigliserida [19,21]. Oleh karenanya, perlu adanya pembatasan konsumsi asam lemak jenuh rantai panjang (> C14).

\section{Kadar Asam Lemak Tak Jenuh Tunggal (MUFA)}

Berdasarkan analisa perbedaan asam lemak tak jenuh tunggal keripik labu kuning metode Vacuum Frying dengan minyak berulang hanya ditemukan kadar asam palmitoleat yang terdistribusi normal. Hasil analisa secara uji statistik perbedaan kadar asam palmitoleat pada keripik labu kuning metode Vacuum Frying dengan minyak berulang tidak ada perbedaan signifikan pada kadar asam palmitoleat dari masingmasing kelompok penggorengan seperti yang ditampilkan pada Tabel 5.1.

Pada penggorengan kondisi vacuum tidak terjadi kerusakan akibat reaksi kimia oksidasi dikarenakan minimnya kontak dengan oksigen. Kerusakan lemak akibat oksidasi dapat berlangsung bila terjadi kontak antara sejumlah oksigen dengan minyak atau lemak [22].

Oksigen, cahaya dan suhu tinggi dapat mengurai asam-asam lemak. Ikatan rangkap yang terdapat pada asam lemak tak jenuh dapat terputus dan oksigen akan menjadi bagian dari molekul [23]. Karena selama penggorengan vakum, kontak dengan udara, terutama oksigen dapat dihindari, maka oksigen tidak dapat menjadi bagian dari molekul tersebut sehingga kerusakan asam lemak tak jenuh dapat diminimalisir.

Berbeda pada penggorengan konvensional dimana minyak kontak langsung dengan udara pada suhu tinggi sehingga mempercepat reaksi oksidasi. Hal ini sesuai dengan penelitian Sartika, 
2009 yang menyebutkan bahwa umumnya kerusakan oksidasi terjadi pada asam lemak tak jenuh yang terkena suhu tinggi lebih dari $100^{\circ} \mathrm{C}$ [24].

\section{Kadar Asam Lemak Tak Jenuh Ganda (PUFA) Asam Lemak Omega 3}

Berdasarkan analisa perbedaan asam lemak tak jenuh ganda keripik labu kuning metode Vacuum Frying dengan minyak berulang hanya ditemukan kadar asam $\alpha$ linolenat (ALA / Alfa Linolenat Acid) yang termasuk ke dalam jenis asam lemak omega 3 dan terdistribusi normal. Hasil analisa secara uji statistik perbedaan kadar asam alpha linolenat pada keripik labu kuning metode Vacuum Frying dengan minyak berulang tidak ada perbedaan signifikan pada kadar asam alpha linolenat dari masing-masing kelompok penggorengan seperti yang ditampilkan pada Tabel 5.2.

Hasil uji menunjukkan bahwa tidak terjadi kerusakan akibat reaksi kimia oksidasi bahan pangan karena proses penggorengan dilakukan dalam kondisi vacuum (hampa udara). Penggorengan dengan metode tekanan menghasilkan asam lemak tak jenuh lebih tinggi dibandingkan dengan penggorengan konvensional. Proses oksidasi dapat dihambat dengan suhu penggorengan yang rendah.

Titik didih minyak akan rendah sehingga tidak ada perubahan pada asam lemak tak jenuh dan kandungan gizinya, penggorengan Vacuum Frying dapat mempertahankan warna sayur dan buah agar tetap menarik dan mengurangi kehilangan vitaminnya [25].

Perlakuan sebelum labu kuning diolah menjadi keripik dengan metode Vacuum Frying juga dapat mempengaruhi reaksi kimia yang terjadi, sebelum digoreng keripik dibekukan. Proses ini memiliki beberapa keuntungan, diantaranya dapat mempertahankan stabilitas produk (menghindari perubahan aroma, warna dan unsur organoleptik lain), dapat mempertahankan stabilitas struktur bahan (pengkerutan dan perubahan bentuk setelah pengeringan sangat kecil), dapat menghambat aktivitas mikroba serta mencegah terjadinya reaksi-reaksi kimia dan aktivitas enzim yang dapat merusak kandungan gizi bahan pangan [26].

Selain itu dengan temperatur yang rendah dapat mengurangi degradasi kandungan mineral pada bahan yang mempunyai sensitifitas panas tinggi, kandungan air dari produk akhir dapat dikendalikan selama proses berlangsung sehingga produk kering mempunyai penampilan yang bagus [27].

\section{Kadar Asam Lemak Tak Jenuh Ganda (PUFA) Asam Lemak Omega 6}

Berdasarkan analisa perbedaan asam lemak tak jenuh tunggal keripik labu kuning metode Vacuum Frying dengan minyak berulang hanya ditemukan kadar asam gamma linolenat (GLA / Gamma Linolenat Acid) yang termasuk ke dalam jenis asam lemak omega 6 merupakan desaturasi pertama dari asam linoleat $(18: 2 \omega 6)$ dan terdistribusi normal. Hasil analisa secara uji statistik perbedaan kadar asam gamma linolenat pada keripik labu kuning metode Vacuum Frying dengan minyak berulang tidak ada perbedaan signifikan $(\mathrm{p}>0,05)$ pada kadar asam gamma linolenat dari masing-masing kelompok penggorengan seperti yang ditampilkan pada Tabel 5.3.

Hal ini sejalan dengan penelitian Crosa et al, 2014 menunjukkan bahwa penggorengan dengan metode Vacuum Frying membuat pengurangan yang jelas dari laju oksidasi. Sehingga tidak terjadi perubahan yang signifikan pada asam lemak tak jenuh yang digoreng dengan metode Vacuum Frying, selain ini penelitian yang dilakukan oleh Carta et al, 2017, juga menyebutkan penggorengan dengan metode Vacuum Frying dapat menghambat proses reaksi 
kimia karena menggunakan suhu penggorengan yang rendah. Penggorengan dengan metode Vacuum Frying dapat menghambat proses terjadinya oksidasi. Kecepatan oksidasi dari asam lemak akan bertambah dengan kenaikan suhu dan berkurang dengan penurunan suhu dalam penggorengan [22].

Penggorengan dengan suhu diatas $200^{\circ} \mathrm{C}$ dapat meningkatkan isomerisasi atau perubahan struktur senyawa hidrokarbon tanpa disertai perubahan rumus molekul, dari PUFA [28]. Isomerisasi ini dapat mengubah ikatan rangkap cis menjadi trans menggunakan sejumlah energi. Dan ketika jumlah ikatan rangkap cis meningkat, energi aktivasi isomerisasi berkurang. Sehingga asam lemak tak jenuh mudah teroksidasi, hal ini sesuai dengan penelitian yang dilakukan oleh Husain dkk, 2016, yang berjudul Pengaruh Suhu dan Lama Penyimpanan Terhadap Komposisi asam Lemak, Angka Peroksida dan Angka TBA Fillet Ikan Kakap (Lutjanus sp) menyebutkan bahwa PUFA lebih cepat teroksidasi pada suhu tinggi daripada MUFA [29].

Reaksi Oksidasi lipida/minyak secara natural mudah terjadi, sebab lemak fillet ikan kakap kaya PUFA (6 ikatan rangkap), sedangkan lemak yang mengandung banyak ikatan rangkap mudah mengalami reaksi oksidasi lipida. Akan tetapi pada suhu rendah kerusakan PUFA dapat diminimalisir.

\section{Perbedaan Asam Lemak Tak Jenuh Tunggal (MUFA) dan Asam Lemak Tak Jenuh Ganda (PUFA) dalam Penurunan Kadar Kolesterol}

Asam Lemak tak jenuh tunggal merupakan jenis asam lemak yang mempunyai satu ikatan rangkap pada rantai atom karbon. Secara umum, lemak tak jenuh tunggal berpengaruh baik untuk kadar kolesterol dalam darah, terutama bila digunakan sebagai pengganti asam lemak jenuh. Asam lemak tak jenuh tunggal contohnya palmitoleat lebih efektif menurunkan kadar kolesterol darah, daripada asam lemak tak jenuh jamak, MUFA memiliki sifat lebih stabil dan lebih baik perannya dibandingkan PUFA. PUFA dapat menurunkan kolesterol LDL, tetapi juga menurunkan HDL. Sebaliknya MUFA dapat menurunkan LDL dan meningkatkan HDL [30]. Penelitian yang dilakukan oleh Wood, menyatakan bahwa MUFA dapat menurunkan LDL dan meningkatkan HDL secara lebih besar daripada Omega3 dan Omega-6.

PUFA dan MUFA keduanya sama-sama berperan dalam penurunan kadar kolestrol total tetapi MUFA selain menurunkan kolesterol total juga terbukti dapat menurunkan LDL dan meningkatkan HDL lebih besar dibandingkan dengan PUFA. Penurunan rasio LDL/HDL akan menghambat terjadinya atherosklerosis.

\section{SIMPULAN}

Berdasarkan hasil penelitian kadar asam lemak jenuh pada keripik labu kuning metode Vacuum Frying pada penggorengan ke 1 , ke 5 dan ke 10 yang dianalisis mengggunakan uji statistik Kruskal Wallis adalah menunjukkan tidak ada perbedaan kadar asam lemak jenuh rantai sedang, seperti:asam kaprilat, asam kaprat dan asam laurat, tidak ada perbedaan kadar asam lemak jenuh rantai panjang, yaitu asam miristat, asam pentadekanoat, asam palmiat, asam heptadeknaoat, asam stearat dan asam arachidat dan tidak ada perbedaan kadar asam lemak jenuh rantai panjang, yaitu asam behenat, asam trikosanoat dan asam lignoserat.

Adapun hasil pengujian asam lemak tak jenuh didapatkan hasil tidak terdapat perbedaan kadar asam palmitoleat keripik labu kuning metode Vacuum Frying dengan penggunaan minyak berulang, tidak terdapat 
perbedaan kadar asam alpha linolenat keripik labu kuning metode Vacuum Frying dengan penggunaan minyak berulang, tidak terdapat perbedaan kadar asam gamma linolenat keripik labu kuning metode Vacuum Frying dengan penggunaan minyak berulang dan asam lemak tak jenuh keripik labu kuning dari penggorengan ke-1, ke-5 dan ke-10 cenderung stabil karena penggorengan hampa dapat mempertahankan nilai gizi termasuk kandungan asam lemak tak jenuh.

\section{UCAPAN TERIMAKASIH}

Terimakasih kepada BPPM FKUB yang telah membiayai penelitian ini sehingga dapat dipublikasikan. Ucapan terimakasih juga dihaturkan kepada Ibu Ely Safitri, AMd Laboran Laboratorium Penyelenggaraan Makanan yang telah membantu proses penelitian ini hingga selesai.

\section{DAFTAR RUJUKAN}

1. Kementerian Kesehatan Republik Indonesia. Riset Kesehatan Dasar. Jakarta : Kementerian Kesehatan Republik Indonesia : 2013. Available from : https//www.depkes.go.id diakses pada tanggal 05/05/2019.

2. Utami YM, Dani Rosdiana, Yanti Emalia. Gambaran Asupan Gizi pada Penderita Sindrom Metabolik di RW 04 Kelurahan Sidomulyo Barat Kecamatan Tampan Kota Pekanbaru. Tidak Dipublikasikan. Riau : Universitas Riau ; 2014.

3. Wahyuni, D. Tepung Labu Kuning (Cucurbita Moschata) Menurunkan Kadar Glukosa Darah Tikus Model Sindroma Metabolik. Jurnal Ilmu Kesehatan. 2017; 2(1): 11-16.

4. Kementerian Kesehatan Republik Indonesia. Tabel Komposisi Pangan Indonesia 2017. Jakarta: Kementerian Kesehatan Republik Indonesia: 2018. Available www//https.kemenkes.go.id diakses pada tanggal 10/05/2019.

5. Lestari Dwi. Aktivitas Antioksidan dan Kandungan $\beta$-Karoten Dodol Labu Kuning dengan Penambahan Bunga Kecombrang Sebagai Pengawet Alami. Tidak dipublikasikan. Surakarta: Universitas Muhammadiyah Surakarta; 2015.

6. Taufik M, Seftiono, H. Karakteristik Fisik dan Kimia Minyak Goreng Kelapa Sawit Hasil Proses penggorengan Dengan Metode Deep-Fat Frying. Jurnal Teknologi. 2018; 10(2): 123-130.

7. Yustinah, Hatini. Adsobsi Minyak Goreng Bekas Menggunakan Arang Aktif dari Serabut Kelapa. Jurnal Pengembangan Teknologi Kimia untuk Pengolahan Sumber Daya Alam Indonesia. 2011; 1-5.

8. Lastriyanto A, Sumardi RY, Melati RM. Karakteristik Kimia Keripik Manalagi Hasil Penggorengan Vakum dengan Menggunakan Minyak Berulang. JKPTB. 2016; 4(1): 157-172.

9. Tumbel N, Manurung S. Pengaruh Suhu dan Waktu Penggorengan Terhadap Mutu Keripik Nanas Menggunakan Penggoreng Vakum. JPTI. 2017; 9(1): 9-22.

10. Herlina $\mathrm{H}$, Astriyaningsih E,Windarti WS, Nurhayati N. Tingkat Kerusakan Minyak Kelapa Selama Penggorengan Vakum Berulang Pada Pembuatan Ripe Banana Chips (RBC). Jurnal Agroteknologi. 2017; 11(1): 186-193.

11. Taufik M, Seftiono, H. Karakteristik Fisik dan Kimia Minyak Goreng Kelapa Sawit Hasil Proses penggorengan Dengan Metode Deep-Fat Frying. Jurnal Teknologi. 2018; 10(2): 123-130.

12. Budijanto S, Sitanggang AB. Kajian Keamanan Pangan dan Kesehatan Minyak Goreng. Jurnal Pangan. 2010; 19 (4): 361-372.

13. Chow CK, et al. Fatty Acids in Foods and Their Health Implications. Third Edition. New York: Penerbit CRC Press; 2008.

14. Sibuea, P. Minyak Kelapa Sawit, Teknologi dan Manfaatnya untuk Pangan 
Nutrasetikal. Jakarta: Penerbit Erlangga; 2014.

15. Kementerian Perindustrian Republik Indonesia. Gambaran Sekilas Industry Minyak Kelapa Sawit. Jakarta : Kementerian Perindustrian Republik Indonesia: 2007. Available from: www//https.kemenperin.go.id.diakses pada tanggal 10/01/2020.

16. Kalapathy dan Proctor dalam Sopianti DS, Herlina, Saputra HT. Penetapan Kadar Asam Lemak Bebas pada Minyak Goreng. Jurnal Katalisator Kopertis Wilayah X. 2017; 2(2): 100-105.

17. Estiasih E, Harijono. Kimia dan Fisik Pangan. Jakarta : Penerbit Bumi Aksara; 2016.

18. Ketaren. Minyak dan Lemak. Jakarta : Penerbit UI Press; 2005.

19. Almatsier S. Penuntun Diet Edisi Baru:Instalasi Gizi Perjan RS Dr. Cipto Mangunkusumo dan Assosiasi Dietesien Indonesia. Jakarta: PT. Gramedia Pustaka Utama; 2010.

20. Winarno FG. Kimia Pangan dan Gizi Edisi Terbaru. Bogor: Penerbit M-Brio Press; 2008.

21. Tuminah. Tinjauan Pustaka Efek Perbedaan Sumber dan Stuktur Kimia Asam Lemak Jenuh Terhadap Kesehatan. Buletin Penelitian Kesehatan; 2010.

22. Ketaren S. Pengantar Teknologi Minyak dan Lemak Pangan. Jakarta: UI-Press; 2005.

23. Mamuaja CF. Lipida. Manado: Unsrat Press; 2017.
24. Sartika RAD. 2009. Pengaruh Suhu dan Lama Proses Menggoreng (Deep Frying) Terhadap Pembentukan Asam Lemak Trans. Depok: Makara, Sains. 2009; 13 (1): 23-28.

25. Widaningrum N, Setyawan DA, Setyabudi. Pengaruh Cara Pembumbuan dan Suhu Penggorengan Vakum Terhadap Sifat Kimia dan Sensori Keripik Buncis (Phaseolus radiatus) Muda. J. Pascapanen. 2008; 5(2): 45-54.

26. Nofrianti R. Metode Freeze Drying Bikin Keripik Makin Crunchy. Jurnal Aplikasi Teknologi Pangan. 2013; 2(1).

27. Fernando LV. Analisa Proses Pengeringan Beku Vakum Aloe Vera dengan Pemanfaatan Panas Buang Kondenser. Tidak dipublikasikan. Depok: Skripsi: Universitas Indonesia; 2009

28. Chen Y, Ying Yang, Shaoping Nie, Xie Yang, Yuting Wang, Meiyan Yang, et al. The Analysis of Trans Fatty Acid Profiles in Deep Frying Palm Oil and Chickeen Fillets with an Improved Gas Chromatography Method. Food Control. 2014; 44:191-197.

29. Husain R, Suparmo, Eni H, Chusnul H. Pengaruh Suhu dan Lama Penyimpanan Terhadap Komposisi Asam Lemak, Angka Peroksidan dan Angka TBA Fillet Ikan Kakap (Lutjanus sp). Dalam AIP Conference Procedings Volume 1755. Yogyakarta; 2016.

30. Almatsier S. Prinsip Dasar Ilmu Gizi. Jakarta: PT Gramedia; 2006. 